\title{
Development of Diploma 4 Fashion Design Curriculum
}

\author{
Ratna Suhartini ${ }^{1, *}$, Yulistiana ${ }^{2}$, Urip Wahyuningsih ${ }^{3}$ Luthfiyah Nurlaela $^{4}$, Elizabeth \\ Titik Winanti ${ }^{5}$, Euis Ismayanti ${ }^{6}$,
}

\author{
${ }^{1,2,3,4}$ Home Economic Department, Faculty of Engineering, Universitas Negeri \\ ${ }^{5}$ Surabaya Civil Engineering Department2 \\ ${ }^{6}$ Electrical Engineering Department \\ *Corresponding author, E-mail corresponding author: ratmasuhartini@unesa.ac.id
}

\begin{abstract}
The development of the fashion design D4 curriculum is the development of the 2018 Fashion Design D3 curriculum. Development of the curriculum follows the 2018 Director General of Higher Education regulations, namely increasing the level of Diploma 3 program to Diploma 4. Increasing levels from level 5 to level 6 SKKNI. This type of research is development research, using the Tressmer model. Development focused on 2: the preliminary stage and the formative evaluation stage focused on 2: the preliminary stage and the formative evaluation stage (Tessmer 1993) which included self-evaluation, prototyping (expert reviews and one-to-one, and small groups), and field tests. The formative evaluation design flow is self-evaluation, prototyping (expert reviews and one-to-one, and small groups), and field tests. The formative evaluation design flow. The results of the D4 Fashion design curriculum development have profiles of garment supervisors, assistant designers, and designers. The curriculum is structured based on several legal grounds for curriculum preparation, vocational curriculum preparation, academic texts, Surabaya State University. The curriculum structure consists of institutional courses and subject areas of expertise. The total number of credits is 144 credits
\end{abstract}

Keywords: curriculum development, Diploma 4 fashion design

\section{INTRODUCTION}

Vocational tertiary institutions have an important role in preparing a skilled workforce, possessing superior knowledge, skills, and character, so that they are ready to engage in the industrial or entrepreneurial world. Vocational Higher Education is a college diploma program that prepares students for certain occupations and applied skills. Vocational Education graduates are required to work competently and become entrepreneurs. Characteristics of vocational education are to provide application and innovative capabilities, prioritizing aspects of practical aspects supported by appropriate theory, the composition of practice is more dominant than theory. (PTV, 2017). The curriculum and learning use a dual system with a composition of 3-2-1, namely three (3) semesters of learning in class, followed by two (2) internships in industry, and ending in one (1) semester to complete education on campus or in industry.

The Fashion Design study program is a vocational education which is generally a Diploma 3 (D3) level. Clothing courses are often also referred to as Clothing Design, Fashion Design or Fashion Design in several universities. The Fashion Design study program studies the techniques of designing, patterning, sewing, and the ins and outs of fashion or fashion production, analyzing trends, marketing, and fashion business management. At the end of the lecture, students of Fashion Design will hold a fashion show as the final work. The course is studied about fashion from the perspective of Paris as a center of world fashion with the mixing of Indonesian culture. The Fashion Management study program at Surabaya State University has a three-tiered Diploma. The name of the study program follows the developments and regulations of the Ministry of Research and Technology, which follows the nomenclature, from its establishment in 1999 to 2018 named D3 Dress Design. In its development, the nomenclature changed the name D3 Dress Design changed to D3 Clothing Design (Apparel Design). In 2017 the D3 Dress Design study program restructured the D3 Dress Design curriculum into D3 Fashion Design, referring to the study program achievements. Learning outcomes of study programs were compiled at the Indonesian Vocational Higher Education Forum in 2015. The curricular restructuring was carried out in various stages, the first stage was conducting workshops involving vocational directors, the second stage was involving industry, the third stage was curriculum development, the fourth stage was focus group discussions, the fifth stage was validation curriculum and the sixth stage is curriculum testing. The curriculum came into force is 2018 with the name D3 curriculum apparel design (apparel design).

The next development was the instruction from the State Gazette of the Republic of Indonesia No. 1500, 2018, Ministry of Research, Technology and Higher Education. Diploma Program in Open Systems at Higher Education. Issued by Minister of Research Regulation. Technology and Higher Education of the Republic of Indonesia Number 54 of 2018 concerning the Implementation of Diploma Programs in the Open System of Higher Education Article 7 that Higher Education that organizes diploma programs can change three diploma programs into four diploma programs to improve graduate competence. This Ministerial Regulation comes into force on the date of promulgation, which is October 30, 2018. The D3 Dress Design study program raises its grade to a Diploma in Fashion Design. 
Development of the D4 Fashion Design curriculum, referring to the D3 Fashion Design curriculum, with the need to analyze market needs, employment and industrial development 4.0. The process of applying the curriculum in vocational learning is done in a package system. D4 design mode is adapted to the nomenclature of the Minister of Technology and Higher Education Ministerial Regulation No.33 of 2018 concerning Naming of Study Programs in Higher Education and the Decree of the Minister of Research, Technology and Higher Education No.57 of 2019. Curriculum development needs to be carried out to conform to government regulations. Adjustment of the name of the nomenclature is done to give the study program identity by the employment needs determined by the government.

Research on curriculum reform in terms of teacher autonomy, for understanding and enhancing the role of teachers in education. The research proposed to analyze whether changes in the curriculum have made significant changes to innovations about the economics teacher. Research findings fail to build teacher coordination and autonomy to encourage taking on a greater role in planning. These plans oppose goals such as development methods that center on student needs, student interests and student support. (Ibrahim, 2011).

Curriculum development is based on an effective delivery strategy contributing its components to achieving quality in teaching and learning. This study describes the strategy and process of curriculum development at The Caledonian college, Oman. The research results show that curriculum development can be made effective through a bottom-up process, joint teaching, development of learning materials, holding intensive staff workshops, developing lesson plans, coaching and guiding new staff, developing different delivery strategies using instructional media. Technology needs to be incorporated into the strategy of updating information about increasing challenges and changes in the education arena (Prekerti, 2015).

Conceptualization of curriculum ergonomics is a field that studies the interaction between users and curriculum material. There are five themes brought about by the lens of ergonomic curriculum, namely: (1) the relationship of the teacher with and the capacity to use curriculum resources; (2) alignment between design intentions and curriculum use patterns; (3) how curriculum resources influence teaching; (4) ways in which curriculum features are deliberately designed to achieve educational goals; and (5) the dissolution of the boundary between design and use. The initial phase summarizes the literature in curriculum ergonomics and then shows how the main themes of the literature inform discussion of curriculum ergonomics (Jeffrey).

The curriculum needs to be developed into certain contexts under certain conditions. Before starting the development it is necessary to analyze the needs of the graduate workforce, the availability of human resources, infrastructure and technological advances that are in force. Development must be planned carefully and maximally. The involvement of curriculum users, namely teachers, is implemented in the curriculum. Teacher development factors are a low priority in Pakistan. Teachers must be trained to be practitioners as reflective research to complete academic and professional teachers. The teacher can facilitate students learning in class. Education policy in Pakistan aims to fail to understand its goals and translate them into curriculum concepts. As a result, most goals remain on paper rather than in practice. Teachers must be encouraged to enrich and update the curriculum at school. This will create an environment of professionalism among teachers who are the real decision-makers of curriculum implementation in the classroom. Teachers as professional practitioners whose advice on curriculum and school management issues must be respected. Curriculum development is done by teachers by creating a framework based on a combination of curriculum management approaches from the top-down and the bottom-up (Ghulam, 2016).

The design and implementation of contemporary curricula need to be applied to appropriate educational practices to improve positive learning and teaching outcomes. This article discusses the study of educational practices and related curriculum antecedents that design and implement Medical Laboratory Technology (MLT) at Mulago Paramedical Schools in Uganda. This study uses quantitative and qualitative methods, document analysis, questionnaires, focus group discussions, and interviews to collect data. The sample consisted of 10 educators, 30 clinical supervisors, and 63 students. The study revealed that the MLT diploma curriculum was implemented with a multi-disciplinary focus to develop the confidence of health professionals and function harmoniously in collaborative teams across disciplines. The study also revealed that curriculum designers and educators adhere to curriculum antecedents and their implementation. A student-centered approach that is oriented towards basic clinical skills and practical competencies. The teaching and learning process is more friendly and interesting. It was concluded that the use of appropriate educational practices during curriculum development was very important. This area of curriculum development is very dynamic research is further needed to ensure the continued relevance of the curriculum in the medical field (Mugimu 2013).

Based on the conditions of curriculum development in Indonesia, it is necessary to conduct a qualitative study of how to develop the D4 Fashion Design curriculum. The focus of this research is the D4 Fashion Design curriculum design at Surabaya State University and the inhibiting factors in developing the D4 Fashion Design curriculum at Surabaya State University.

\section{LITERATURE REVIEW}

\section{Curriculum Development}

According to Law no. 20 of 2003, the curriculum is "A set of plans and arrangements regarding the objectives, content, and learning materials and ways used as guidelines for organizing learning activities to achieve certain educational goals". (Chapter I Article 1 paragraph 19). The curriculum has 4 main components, namely: (1) objectives; (2) contents and materials; (3) strategy, learning; (4) curriculum organization and. The four components have a close and inseparable connection. Sanjaya (2010) describes, the curriculum as a planning document that contains the objectives to be achieved, the contents of the material and learning experiences that students must do, the categories and ways that can be developed, evaluations that are designed to gather information about achieving goals, as well as the implementation of documents designed in concrete form. The curriculum is a channel that helps teachers and other agents to provide education to future generations. the difference between theories must involve practitioners who have relevant and sufficient teaching and learning experience to develop (Mugimu, 2013). 
Curriculum development according to Zaini (2012) is an activity that produces a curriculum, or a process that links one component with another component to produce a better curriculum or the activities of preparation, implementation and evaluation as well as activities for curriculum improvement and improvement. While Wahyudin (...) revealed that curriculum development is a comprehensive term that includes planning, implementation and evaluation because curriculum development shows changes and progress. According to Hamalik (2017), curriculum development is a curriculum planning process in order to produce broad and specific curriculum plans.

The principles of curriculum development include relevance, effectiveness, efficiency, sustainability, and flexibility. Relevance includes the relevance of education in the environment of students, relevance to the development of present and future lives, relevance to the demands in the world of work. Besides the relevance in terms of the content of Education and relevance in terms of learning activities. Effectiveness includes the effectiveness of teacher teaching and student learning. The efficiency of a business is basically a comparison between the results achieved with the effort that has been issued in terms of time, energy, and equipment, costs. Continuity of relationships or intertwining between various levels and types of Education programs. Continuity between various levels of schooling, and continuity between various fields of study. Flexibility, not standard, includes flexibility in choosing programs and flexibility in developing teaching programs.

The elements of the curriculum are: a) goals: National Education goals and goals of the Educational Institution b) Matter (subject matter) tailored to the objectives, syllabus and scientific knowledge, c) organizing (curriculum implementation strategy) d) evaluating (evaluating curriculum) evaluating assessment of inputs (funds, infrastructure, students), learning processes, outputs (assessment of graduates of Education) and outcome (ability of graduates to carry out their duties and responsibilities) (Nasution, 2008).

The Higher Education Curriculum is developed by each tertiary institution with reference to the National Higher Education standards for each study that includes the development of intellectual intelligence, noble character, and skills (UUPT No. 12/2012 Article 35 paragraph 1). Curriculum development is the process of curriculum planning and preparation by curriculum developers and activities undertaken so that the resulting curriculum can become teaching materials and references used to achieve national education goals. The development of multi-entry and multi-exit curriculum models is strengthened by Law Number 21 of 2012 concerning Higher Education and Presidential Regulation Number 8 of 2012 "Kerangka Kualifikasi Nasional Indonesia" (KKNI). KKNI is a competency qualification selection framework that can juxtapose, equalize, and integrate education, job training and work experience in the context of providing recognition of work competencies according to the work structure in various sectors. KKNI illumination will strengthen the accountability of the administration of education while ensuring the quality of graduates.

Vocational higher education curriculum development refers to: 1) national economic development programs 2) producing graduates who are able to respond to market needs, 3) producing tangible work that is valuable /contribute economically. The development of vocational higher education curriculum has the following characteristics: 1) involves associations, industries, stakeholders, 2) the contents of the course emphasize applied competencies, 3) according to the needs of the job market and industry development, 4) carried out in a package system. UUPT No. 12/2012 Article 35 states, the Higher Education curriculum for undergraduate and diploma vocational programs must contain subjects: 1) Religion. 2) Pancasila, 3) Nationality and 4) Indonesian. While Permenristekdikti 44 article 17 explains the courses in vocational education include: 1) theory, 2) practicum, 3) workshops. 4) practical work 5) Final project. The learning system used is a package system, which is designed from the beginning semester to the final semester in sequence, students do not need to choose courses freely. Students must complete all courses in one semester before proceeding to the next semester.

Student learning load as referred to in Article 6 paragraph (2) letter $d$ is stated in the number of credits, (1) one credit is equivalent to 170 minutes of learning activities per week per semester. (2) Semester, as referred to in paragraph (1), is a unit of time for effective Learning activities for 16 (sixteen) weeks including evaluation of learning outcomes. (3) 1 (one) SKS in the form of lecture learning, responsiveness, and tutorials, covering face-to-face learning activities 50 (fifty) minutes per week per semester, learning activities with structured assignments 60 (sixty) minutes per week per semester, independent learning activities 60 (sixty) minutes per week per semester. (4) One SKS form of seminar learning or other similar forms of learning, covering face-to-face activities 100 (one hundred) minutes per week per semester, independent learning activities 70 (seventy) minutes per week per semester. (5) One SKS in the form of practicum learning, studio practice, workshop practice, field practice, research, community service, and / or other forms of learning that are equivalent to 170 (one hundred seventy) minutes per week per semester (120 (one hundred -17 - twenty) minutes of practice, 50 (fifty) minutes of independent assignments). (6) The period and burden of learning in organizing educational programs: a. a maximum of 4 (four) academic years for a diploma program of three, with a student learning a load of at least 108 (one hundred and eight) SKS; b. a maximum of 5 (five) academic years for a four / undergraduate diploma program, with a student learning a load of at least 144 (one hundred forty-four) SKS. Article 14 A student is declared to have passed if he has taken all of the specified learning burdens as referred to in Article 9 paragraph (6) and has a learning achievement of graduates targeted by the Study Program with a Grade Point Average (GPA) greater or equal to 2.50 (two commas five-zero) without a grade D. Students who have been declared graduated as referred to in paragraphs (1) and (2) are entitled to: a. diplomas, for graduates of diploma programs and applied master programs; b. transcripts; c. certificate of competence, e. Certificate of Companion Diploma (SKPI); and f. Degree.

The understanding used in the guidelines for the preparation of vocational curriculum in UUPT No.12 of 2012 explanation of article 16 paragraph 1) an education that prepares students to become professionals with high work skills/abilities. The vocational education curriculum is prepared together with professional societies and professional organizations responsible for the quality of professional services to meet the professional competency requirements. Thus, vocational education has included professional education. b) The curriculum is a set of plans 
and arrangements regarding graduate learning outcomes, study materials, processes, and assessments that are used as guidelines for organizing professional education study programs in several specialized and vocational-based knowledge fields (application of appropriate technology). The curriculum in vocational tertiary education has the following characteristics: 1 . The preparation of the curriculum involves associated Associations, Industries, and Stakeholders 2. The curriculum content consists of courses that emphasize applied competencies 3. Curriculum development is carried out by the needs of the job market and industrial development 4 . The process of applying the curriculum in vocational learning is done in a package system.

The Fashion Diploma Diploma curriculum is a study program curriculum that refers to several government rules and refers to the academic paper of Surabaya State University in 2018. Each curriculum that applies in every study program at Surabaya State University is a design experience to develop student competencies according to the level of competency of graduates according to KKNI in the study program pursued, according to the study program's characteristics, the competency elements formulated include attitudes, general skills, awareness, and special skills. The attitude competency formula is in line with the character that is developed in the students of Surabaya State University, which is growing with character, namely faith, intelligent, independent, honest, caring, and tough (Idel Jelita). The material for the study of Surabaya State University is packaged in courses, namely faith, communicating in English, independent, intelligent, honest and tough entrepreneurial spirit, care. care. The curriculum structure consistas of institutional courses and vocational skills. The basic framework of the D4 curriculum includes the subjects of Religion, Pancasila Education, Indonesian, ISBD, KKN, Philosophy, English, entrepreneurship PKL I, PKL II, and Final Projects. The courses specified in the study program are courses related to the academic competence of the main study substance following 6 levels of the KKNI.

\section{METHOD}

This type of research is development research Development is focused on 2: the preliminary stage and the formative evaluation stage (Tessmer 1993) which includes selfevaluation, prototyping (expert reviews and one-to-one, and small groups), and field tests. The formative evaluation design flow is as follows.

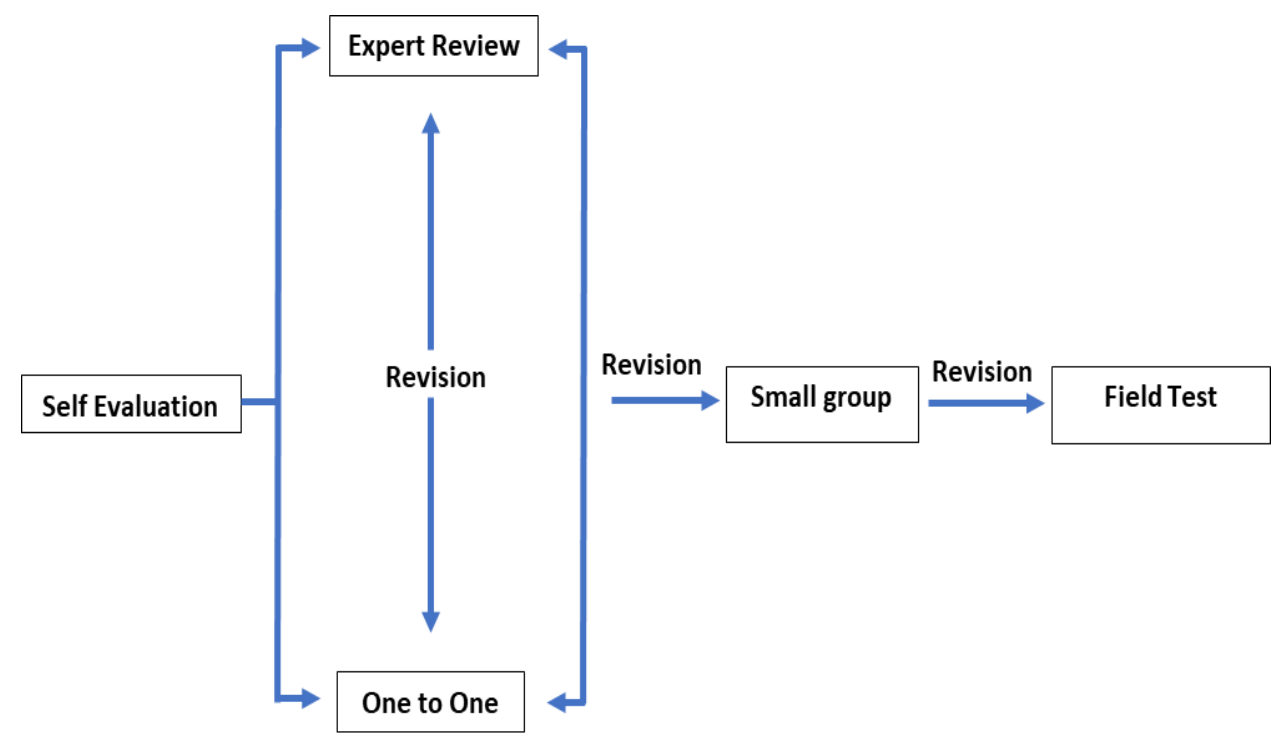

\section{Preliminary Step}

At this stage, the researcher determines the place and subject of the study. The research location of the D4 Fashion Design study program, the research subjects are stakeholders, the head of the study program, the homebased lecturer in the D4 Fashion Design study program. The researcher arranges the research schedule and procedures for collaboration with stakeholders and homebased lecturers.

\section{Formative Evaluation Step}

Self Evaluation includes a) the analysis phase is the initial step of development research. Researchers, in this case, will conduct student analysis, curriculum analysis, and analysis of the device or material to be developed. b) the design stage the researcher will design the device to be developed which includes designing the grid, the objectives, and the method to be developed. Then the design results that have been obtained can be validated the existing validation techniques namely the design is validated by experts (experts) and colleagues. The results of this designation are referred to as the first prototype.

Prototyping The results of designing the prototype developed based on self-evaluation are given to experts (expert review) and students (one-to-one) in parallel. From the results of both of them used as revised material. The results of the revision of the prototype are called the second prototype. Prototyping consists of stages: a) the stage of expert review, at this stage the product that has been designed is examined, assessed and evaluated by the expert. The experts examined the content, constructs, and language of each prototype. Expert recommendations were used to revise the tools developed. At this stage, the responses and suggestions from the experts (validators) about the designs that have been made are written on the validation sheet as revising the material and states that whether this design has 
been valid or not. b) One-to-one stage, at this stage the researchers tested the design that has been developed for students who become testers. The results of this implementation are used to revise the design that has been made, c) the small group stage. The results of the revision of the expert and the difficulties experienced during trials on the prototype were used as the basis for revising the prototype and named the second prototype then the results were tested on a small group. The results of this implementation are used for revision before being trialed at the field test stage. The results of the question revision are based on students' suggestions/comments on the small group and the results of the analysis of this item are called the third prototype.

Field Test Suggestions, as well as the results of trials on the second prototype, serve as the basis for revising the design of the second prototype. The results of the revision were tested on research subjects in this case as a field test. Products that have been tested in the field test must be products that have met the quality criteria. Akker (1999) suggests that three quality criteria are: validity, practicality, and effectiveness (having potential effects).

\section{RESULTS AND DISCUSSION}

\section{The Legal Foundation for the Development of Curriculum D4 Fashion Design}

Development of curriculum D4 Design mode takes into account the provisions in force in Indonesia. The legal basis for developing curriculum D4 Fashion design refers to a) Law No. 20 of 2003 concerning the National Education System, in Chapter VI of article 15, article 19, article 20 and article 21 b) Law No. 12 of 2012 concerning Higher Education, in Chapter I article 5 and Chapter II article 16 c). Government Regulation No. 4 of 2014 concerning Implementation of Higher Education and Management of Higher Education d). Government Regulation No. 19 of 2005 concerning National Education Standards e). Republic of Indonesia's Presidential Regulation No. 8 of 2012 concerning the Indonesian National Qualification Framework f). Minister of Research, Technology and Higher Education Regulation No. 44 of 2015 concerning National Standards of Higher Education h. Minister of Research, Technology and Higher Education Regulation No. 13 of 2015 concerning the Strategic Plan of the Ministry of Research, Technology and Higher Education 2015 - 2019. g) Regulation of the Minister of Research. Technology and Higher Education of the Republic of Indonesia Number 54 of 2018 concerning the Implementation of Diploma Programs in the Open System of Higher Education Article 7 that Higher Education that holds a diploma program three can change a diploma program three into a diploma program four to improve graduate competency. h) Academic Manuscript of Surabaya State University in 2018.

\section{Self-Evaluation}

Curriculum development is done by evaluating the existing curriculum, the D3 Fashion Design curriculum in 2017. Evaluation is done by involving alumni and stakeholders. Tracer for alumni who have worked, the type of work and competence and about the relevance of subject areas taught while sitting in college. From the tracer obtained, all graduates work according to their competencies. Type of party fashion planner work in the fashion industry. Party fashion planner is meant to make a party fashion starting from planning the design, planning the materials, choosing the main ingredients and additional materials and accessories, and cutting the material. The work of sewing, decorating and finishing is done by other employees. Quality control and submission of orders are carried out by graduates. In addition to working in the industry, entrepreneurial graduates open their businesses, namely receiving orders for party clothing, bridal clothing. It also opens a business by ordering and selling online. The responses from stakeholders about students who did industrial internships and graduates who just came to work were: 1) students lacked dexterity in carrying out their assignments, 2) communication with company owners and employees was not friendly 3 ) attitudes toward accepting customers were less confident. 4) lack of great responsibility for work. Graduates' competencies still have to adjust to the character in the industry. After working for 1 month, students are able to adjust themselves to competencies in the industry and workplace conditions.

The subjects taught according to graduates can already be made the basis for work. However, in the course material there are too many types of practice, so the results of practice done by students not all students get the results as expected. Some suggestions from students, practices are grouped according to the type of clothing practiced. Online marketing also needs to be included in the lecture material. Curriculum D3 of 2017 Fashion Design still does not fully refer to Indonesian National Work Competency Standards. Some competency units have not been mapped in the curriculum. The curriculum only refers to industry standards and academic texts of Surabaya State University.

\section{Prototyping}

The results of the curriculum evaluation above become a reference for the D3 Fashion Design curriculum 2018. Curriculum Design in D3 Fashion Design continues to refer to a) Academic Manuscripts of the Surabaya State University in 2016. b) Classifying material practice patterns and the production of clothing and similar practice materials, c) referring to SKKNI, by putting SKKNI into the curriculum structure. The D3 curriculum design for Clothing Design was validated by experts namely 5 designers in East Java. After validation by the expert, a focus group discussion (FGD) is conducted. FGD material is the suitability of the name of the course with the terms in the world of fashion, course material, the proportion of practice in each subject, the proportion of practice and forms of practice as well as the assessment of practice results. The result of the FGD is to add some material to several subjects, each practice course produces products according to the passion of students.

From the validation, results obtained Diploma D3 Profile Clothing design is an assistant designer. The curriculum structure is divided into 3 competency groups, namely: a) in year 1: discover, preparation, and basic skills, b) year 2 in the creation and advance skills, 3) year 3 in specialization and personal collection. The courses are grouped into 4 groups. a) The Fashion Design Group includes Mode I design, Mode II design, Mode III design, Mode IV design, and accessories design. b) textile groups include: textiles and materials, textile design I, textile design 2 , textile design 3 , and textile design 3 , c) fashion studio group including: fashion studio I, fashion studio II, fashion studio III, fashion studio IV, fashion studio V, Children's wear, and Draping, d) industrial fashion groups include: fashion 
concept, garment \& quality control, fashion business, fashion marketing \& branding, professional ethics, communication \& excellent service. Industrial work practice courses are carried out 2 times, this is in accordance with the academic text of Surabaya State University, and the rules in vocational education, the proportion of theory and practice is 3: $2: 1$, namely the theory of 3 classes learning in class, 2 semesters of study in industry and 1 semester of study in class or in industry.

Based on expert input and FGD results, the D4 Fashion Design curriculum was compiled. D4 curriculum is the D3 curriculum for Fashion Design. Adding several subjects and rearranging the subjects into 3 main competencies, namely in the first year is the garment supervisor, the third-year assistant designer, and the fourth year designer. Determination of the competency refers to the Regulation of the Minister of Research and Technology of the Republic of Indonesia Number 54 of 2018 concerning the Implementation of Diploma Programs in the Open System in Higher Education, namely Article 7 stating that Higher Education implementing three diploma programs can change diploma program three into diploma program four for improving graduate competence. Furthermore, it is said that students can get a certificate of competence in the 2nd, 3rd and 4th years of getting an applied undergraduate diploma. The results of the development of the D4 Fashion Design curriculum structure are as follows.

The first two years, with the main competence of supervisors. Supporting courses from semester 1 to semester 4 are Semester 1: Pancasila, Indonesian, English, Introduction to the Fashion Industry, Industrial \& K3 Machinery, Textile Material Knowledge, Fashion Design I, Fashion Studio I, Computer Graphics. Semester II: religion, citizenship, Digital Literacy, Textile Design I, Fashion Design II, Fashion Studio II, Draping, CAD. Semester III: Physical Education, Culture and Global Issues, Communication and Excellent Service, Garment \& QC, Grading \& Marking, Textile Design II, Fashion Design III, Fashion Studio III. Semester IV: Clothing History, Fashion Forecasting, Fashion Marketing, Garment \& QC Practices, Textile Design III, Men's Clothing, Internship 1.

Third year with the main competence of assistant designers. Supporting courses, in addition there are in semester 1,2,3, and 4, semester V courses: Fashion Buying \& Merchandising, Entrepreneurship, Design Thinking, Design Mode IV, Bridal Clothing, Internship 2. Semester VI: Writing Scientific Papers \& Seminars, Professional English, Clothing Production IV, Accessories, Fashion Show Management, Design \& Product Development, Branding Development

Year 4 with Designer competency, VII semester courses: Advance Draping, Final project. 3. Semester VIII: Internship

Preliminary analysis is carried out on the adequacy of the curriculum for competencies in the KKNI and SKKNI. The curriculum meets the KKNI requirements. Conformity with KKNI is sufficient in the course. Not all course names are the same as the competency unit names in SKKNI. There are courses that are the same as the competency units, some are not the same, but the material from the competency units needed is entered in the course. The courses in the curriculum structure are in accordance with the academic text of Surabaya State University, the main character is communicating with English, digital literacy and Physical Education. The curriculum is also in accordance with the guidelines for the preparation of vocational curriculum, namely there are courses 1) Religion. 2) Pancasila, 3) Nationality and 4) Indonesian. The total number of credits is 144 credits. The proportion of theory and practice is $33 \%$ theory and $67 \%$ practice. The implementation of fieldwork practices is carried out 3 times, namely 4,5 , and 8 semesters.

The resulting curriculum draft was validated by experts with a background in Clothing Education. The curriculum also began to be tested on D4 Clothing Design Class 2018. The results of expert validation are as follows: Learning methods, learning models, infrastructure, and facilities, work practices in industry: time in industry needs to be blocked in several subjects that are possible for industry and teaching factory on campus. The proportion of theory and practice 30:70. There are courses on digital literacy, digital textile design. Physical Education courses are associated with the field of fashion. Graduates' profiles as fashion designers need to be equipped with full capabilities. The memes for the second year are in accordance with level 4 KKNI. Learning outcomes have been met in accordance with level 5 and the FPTVI association.

Some expert input has been covered in the curriculum. The percentage between theory and practice is following the minimum requirements in vocational training, the minimum requirement is 40\%: $60 \%$. The proportion of D4 Fashion Design practice is 33\%: 67\%. While the Physical Education course is purely not related to the field of fashion.

\section{Field Test}

Suggestions on the D4 Fashion design curriculum prototype after revision were tested on research subjects, in this case, D4 Fashion Design 2019 students. refer to SKKNI. The first trial was conducted in the semester I courses. Institutional courses were theoretical courses, carried out following the planned credits, which were 2 credits. The subject area of expertise weights 2 credits, the proportion of theory and practice is 1: 1 . Subjects that weight 3 credits, the proportion of theory and practice is $1: 2$. Subjects that have a credit score of 4 , the proportion of theory and practice is $1: 3$.

\section{CONCLUSION}

D4 Fashion Design curriculum development refers to several regulations, namely: Law on the National Education System, Law on Higher Education, Government Regulations on the Implementation of Higher Education and Management of Higher Education, Government Regulations on National Education Standards, Presidential Regulation on the Framework Indonesian National Qualifications, Regulation of the Minister of Research, Technology and Higher Education, concerning National Standards of Higher Education, Regulation of the Minister of Research, Technology and Higher Education, on the Strategic Plan of the Ministry of Research, Technology and Higher Education, Regulation of the Minister of Research. Technology and Higher Education of the Republic of Indonesia concerning the Implementation of Diploma Programs in Open Systems at Universities.

The D4 Fashion Design curriculum development involves associations namely FPTVI, stakeholders, home-based lecturers, department leaders, and faculty leaders. Curriculum development is carried out in accordance with market developments, namely the demand from the garment industry. The curriculum contains compulsory subjects according to (UUPT No. 12/2012 article 35 
[10] Mugimu, C. And Mugisha, W. (2013) Educational Practices Curriculum Design And Implementation At The Mlt Diploma Program In Uganda. Creative Education, 4, 105-115. Doi: 10.4236/Ce.2013.412a2016.

paragraph 1), namely: Religion, Pancasila, Citizenship, and Indonesian Language. The curriculum also includes compulsory subjects at Surabaya State University, namely: English, Digital Literacy, and Physical Education. The learning system applies a package system, there are no elective courses, and curriculum courses include theory, practicum, workshops, fieldwork, and final projects. The total number of credits is 144 credits. One semester that is starting weeks 1 to 16 . And the proportion between theory and practice $33 \%$ theory $67 \%$ practice.

\section{REFERENCES}

[1] Wina Sanjaya, Kurikulum Dan Pembelajaran, Teori Dan Praktek Pengembangan Ktsp, (Jakarta: Kencana, 2010), 32

[2] Muhamad Zaini, Pengembangan Kurikulum, (Jogjakarta: Diva Press, 2012), 28.

[3] Din Wahyudin, Manajemen Kurikulum ( Pt Remaja Rosdakarya: Bandung Rosdakarya), 62

[4] Oemar Hamalik Dasar-Dasar Pengembangan Kurikulum, (Bandung: Remaja Rosdakarya, 2007), 183

[5] Nasution, Asas-Asas Pengembangan Kurikulum, (Jakarta: Bumi Aksara, 2008), 6

[6] Tessmer, Martin. 1998. Planning And Conducting Formative Evaluation. Philadelphia. Kogan Page

[7] Naskah Akademik Unesa, Tahun 2016

[8] Lias Hasibuan, 2010 Kurikulum Dan Pemikiran Pendidikan, Jakarta: Gaung Persada,

[9] Oemar Hamalik, 2013 Kurikulum Dan Pembelajaran, Jakarta: Bumi Aksara
[11] Ghulam Haider. 2016. Process Of Curriculum Development In Pakistan. International Journal Of New Trends In Arts, Sports \&Science Education - 2016, Volume 5, Issue 2

[12] Jeffrey Choppin. Dkk. Curriculum Ergonomics: Conceptualizing The Interactions Between Curriculum Design And Use. International Journal Of Education Research Volume 92, Pages 75-85

[13] (Ms. Prekerthi Panika Dkk. 2015.Best Practices In Curriculum Development \& Delivery With Special Reference To Educational \& Professional Development Department At Caledonian College Of Engineering, Oman. International Journal Of Education And Research Vol. 3 No. 4 April 2015)

[14] (İbrahim Hakkı Öztürk Curriculum Reform And Teacher Autonomy In Turkey: The Case Of The History Teaching. International Journal Of Instruction. July $2011 \bullet$ Vol.4, No.2)

[15] Https://Ristekdikti.Go.Id/Kabar/RakernasKemenristekdikti-2019-Lahirkan-Tujuh-FokusRekomendasi/

[16] Http://Fatkhan.Web.Id/Karakteristik-Dan-Tu Ntutan-Perkembangan-Pendidikan-Kejuruan/ 